\title{
Analiza stavova $i$ interesa učenika srednjih škola o prirodnim vrijednostima Međimurske županije
}

\author{
Monika Cindrić1, Mihaela Mesarić2 ${ }^{2}$ Dražen Crnčec $^{3}$ \\ 1 Srednja škola Čakovec \\ monica.pbk@gmail.com \\ ${ }^{2}$ Međimurska priroda - Javna ustanova za zaštitu prirode \\ ${ }^{3}$ OŠ Sveti Martin na Muri
}

\section{SAŽETAK}

Zadaća ekološke edukacije je prenijeti poruku o značaju i nužnosti očuvanja prirodnih i drugih vrijednosti, a najmoćnijim sredstvom ekološke edukacije smatra se interpretacija. Već je začetnik interpretacije Freeman Tilden istaknuo: „Interpretacijom do razumijevanja, razumijevanjem do poštovanja, poštovanjem do zaštite." Korištenjem izravnih i neizravnih oblika interpretacije, od strane djelatnika Međimurske prirode - Javne ustanove za zaštitu prirode i dvoje nastavnika osmišljen je edukativni program "Mladi čuvari prirode Međimurja“. Predmetni odgojno-obrazovni program polazilo je četrdesetak učenika šestih i sedmih razreda osnovnih škola s područja Međimurske županije. Program je realiziran kroz predavanja, radionice i terenski rad tijekom proljeća 2009. godine s ciljem ekološke edukacije učenika o prirodnim vrijednostima Međimurske županije i povećanjem interesa za prirodoslovlje. Cilj ovog rada bio je utvrditi utjecaj programa "Mladi čuvari prirode Međimurja“ na razvoj pozitivnijih stavova o zaštićenim dijelovima prirode na području Međimurske županije te povećanju interesa za prirodoslovlje. Stavovi učenika ispitani su online anketom. $U$ anketiranju su sudjelovali polaznici programa iz 2009. godine, a kao kontrolna skupina njihovi vršnjaci koji nisu sudjelovali u programu. $U$ anketi se, osim stavova, ispituju i interesi iz područja prirodoslovlja s posebnim naglaskom na zaštićene dijelove prirode. Istraživanjem je potvrđena hipoteza da postoji razlika u interesu za prirodne vrijednosti Međimurske županije između polaznika programa „Mladi čuvari prirode Međimurja“ i nepolaznika. Također, polaznici programa imaju veće znanje o prirodnim vrijednostima Međimurske županije od nepolaznika.

Ključne riječi: priroda; zaštićene prirodne vrijednosti; mladi čuvari prirode; stavovi o prirodi

\section{UVOD}

Ekološka edukacija je širom svijeta među najvažnijim i najpopularnijim funkcijama zaštićenih područja. Zadaća ekološke edukacije je prenijeti poruku o značenju i nužnosti očuvanja prirodnih i drugih vrijednosti u zaštićenom području, ali i ukupnoga okoliša izvan zaštićenih područja (Martinić, 2010). Najznačajnije sredstvo geoedukacije, edukacije za očuvanje prirode i održivi razvoj, je interpretacija te se njome mogu prenijeti poruke o interesima zaštite prirode $\mathrm{i}$ ispravnom ponašanju u nekom području u cilju njegove zaštite (Gray, 2005). „Interpretacija“ je edukacijska aktivnost koja ima za cilj otkriti značenje prirodnih i kulturnih resursa. Kroz brojne medije interpretacijom se povećava naše razumijevanje, uvažavanje te posljedično i zaštita baštine (Bunić, 2006). Već Tilden (1977) ističe: „Interpretacijom do razumijevanja, razumijevanjem do poštovanja, poštovanjem do zaštite...".

Obrazovna politika 21. stoljeća nastoji staviti kvalitetu ispred opsega trajnih znanja, drugim riječima, važnije je stvoriti trajne temelje za stjecanje novih spoznaja tijekom cijelog života. Upravo zato, više od jednog desetljeća Europa prepoznaje potrebu za poticanjem mladih na bolje usvajanje prirodoslovnih obrazovnih sadržaja (Council of the European Union, 2001). No, postoje spoznaje da već u osnovnom obrazovanju počinje opadati interes učenika za sadržajima iz prirodoslovlja (European Commission, 
2007), a što daju naslutiti i neka istraživanja provedena u Hrvatskoj (Lenardić i sur., 2005; Baranović, 2006). Dakle, sigurno je da barem u malom dijelu na takvo stanje ima utjecaj i ustroj prirodoslovnih sadržaja u hrvatskom nacionalnom okvirnom kurikulumu te sam obrazovni proces u školama. Stoga suvremena nastava prirodoslovlja očekuje da učenici usvajaju prirodoznanstvenu metodu i prirodoslovne postupke otkrivanja i dolaženja do znanstvenih spoznaja u prirodoslovlju, kako bi se osamostalili u istraživanju okoliša (De Zan, 1999). U navedenom je potrebno posebnu brigu posvetiti i interdisciplinarnosti.

Metodička istraživanja pokazuju da su najbolje rezultate u prirodoslovlju postigli učenici koji su prirodu spoznavali kao znanstvenici, istraživačkom metodom, primjenjujući prirodoznanstvenu metodu, odnosno stjecali pojmove iz prirodoslovlja polazeći od postavljene pretpostavke, putem samostalnog motrenja, istraživanja i bilježenja promjena, do zaključivanja (Klausmeier i Sipple, 1980). Poznato je da najbolje rezultate postižu učenici u školi u slobodnim i izbornim aktivnostima, gdje nema ocjenjivanja kao u drugim nastavnim predmetima, već učenicima daju poticaj mogućnosti objavljivanja imena ili određenog rada u školskim novinama, sudjelovanja na smotri ili jednostavno zadovoljstvo sudjelovanja u nekom zanimljivom projektu (Matijević, 2004). Navedeno je bio osnovni poticaj kreiranju programa "Mladi čuvari prirode Međimurja“. Kako bi program obogaćivanja (u ovom slučaju prirodoslovnih sadržaja) bio uspješan, on mora postaviti ciljeve, učenje učiniti uzbudljivim i dovesti do boljeg razmišljanja (George, 2005). Sve aktivnosti nadopunjavanja i obogaćivanja postojećih nastavnih planova i programa prirodoslovlja treba stoga planirati i osmišljavati na način da omoguće dodatni rad i potiču motiviranost učenika, koriste složeniji znanstveni rječnik, zadaju zadatke $s$ više mogućnosti rješenja te omogućuju kreativno mišljenje i mogućnost odabira sadržaja od strane učenika.

Program „Mladi čuvari prirode Međimurja“ zamišljen je kao izvanškolska aktivnost koja se provela prema definiranom planu i programu s učenicima šestih i sedmih razreda 2009. godine, a s kojim su bile upoznate sve osnovne škole Međimurske županije te roditelji polaznika programa koji su trebali dati i svoju pismenu suglasnost za sudjelovanje. U programu je sudjelovalo četrdeset i četvero učenika iz 18 osnovnih škola s područja Međimurske županije. Interdisciplinarni programski sadržaji podijeljeni su u 5 dana odnosno 32 sata (tablica 1), a održali su se u Centru za posjetitelje u Križovcu te na terenu. U prvom terminu sudionici programa su se upoznali međusobno is predavačima te su kroz interaktivno predavanje dobili uvod $u$ zaštitu prirode $i$ načine zaštite prirodne baštine. $U$ drugom terminu su provedene interaktivne radionice vezane uz fizičko-geografske elemente Međimurja, krajobraznu raznolikost te ugroženu floru i faunu Međimurja. Ovaj termin je obuhvaćao i praktičan rad na primjerima iz neposredne stvarnosti (npr. analiza prehrane sova) kao i izradu tematskih prezentacija. Treći i peti termin, terenska nastava, su bili organizacijski najzahtjevniji. U trećem terminu obiđena su značajnija zaštićena područja Međimurja (Značjani krajobraz rijeke Mure i Spomenik prirode Bedekovićeve grabe), a u petom terminu je posjećen Park prirode Papuk te su učenici detaljnije upoznati s pojmom georaznolikosti. $U$ četvrtom terminu polaznici programa su prezentirali naučeno; predavačima i medijima. Program je za sve polaznike bio besplatan.

Tablica 1. Plan i program aktivnosti programa "Mladi čuvari prirode Međimurja“

\begin{tabular}{|l|l|}
\hline \multicolumn{1}{|c|}{ DATUM } & \multicolumn{1}{c|}{ AKTIVNOST I VREMENSKI OKVIR } \\
\hline 21. ožujka 2009. & Uvod u zaštitu prirode i načini zaštite prirodne baštine (5 sati) \\
\hline 28. ožujka 2009. & Prirodne vrijednosti Međimurja (5 sati) \\
\hline 04. travnja 2009. & Terenski izlazak - zaštićena prirodna područja u Međimurju (7 sati) \\
\hline 22. travnja 2009. & Dan planeta Zemlje - predstavljanje polaznika i programa javnosti (2 sata) \\
\hline 02. svibnja 2009. & Terenski izlazak - PP Papuk (13 sati) \\
\hline
\end{tabular}

Broj 4, prosinac 2018, 
U podizanju ekološke svijesti od posebne su važnosti škola i nastavni proces koji različitim metodama i postupcima podižu stupanj odgoja i obrazovanja koji pridonosi zaštiti i unapređivanju ljudskog okoliša (Matas, 1999). Stoga se ovaj edukativni program temelji na pretpostavci da odabrane teme iz prirodoslovlja treba primijeniti u svrhu edukacije učenika šestih i sedmih razreda osnovne škole, posebice potaknuvši učenike u svladavanju osnovnih prirodoslovnih i ekoloških pojmova s naglaskom na učenje o prirodnim vrijednostima Međimurske županije. On ima za cilj da pomoću suvremenih metoda poučavanja teme iz prirodoslovlja približi učenicima posredstvom neposredne stvarnosti. Dakle, sadržaji su eksplicitno povezani sa svakodnevnim životom i aktivno prikazani kroz civilizacijsku ulogu (Štrbić, 2006).

Kod izrade programa slijedila se misao da treba povezati sadržaje iz različitih predmeta, a prvenstveno prirode, biologije i geografije te informatike i likovnog odgoja. $U$ tom području ostvarene su logičke poveznice kroz programske sadržaje. Informatika i prirodoslovlje omogućuju mišljenje orijentirano na fundamentalnost. Dakle, povezuje se "različito" (Jelavić, 1995). Korištenjem informacijskokomunikacijske tehnologije, korelacija među nastavnim predmetima i područjima te uporabom programirane nastave, portfolia, mentalnih mapa i terenske nastave, programu je bio cilj razvoj pozitivnijih stavova o zaštiti prirode te povećanje interesa za prirodoslovlje.

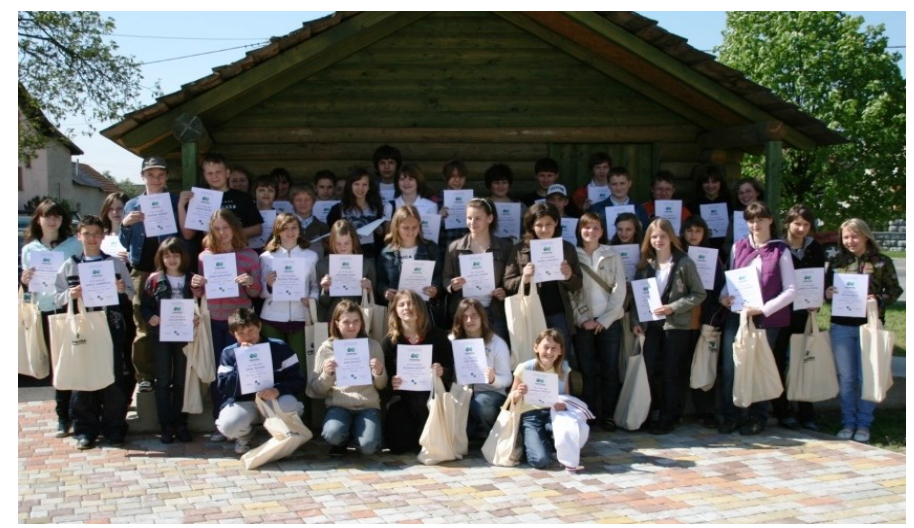

Slika 1. Polaznici programa „Mladi čuvari prirode Međimurja“ 2009. godine

Stoga se ovim radom utvrđuje utjecaj programa „,MMladi čuvari prirode Međimurja“ " na razvoj pozitivnijih stavova o zaštićenim dijelovima prirode na području Međimurske županije te povećanju interesa za prirodoslovlje. Istraživanjem se osim stavova ispituju i interesi iz područja prirodoslovlja s posebnim naglaskom na zaštićene dijelove prirode slijedeći hipoteze:

$\checkmark$ Postoji razlika u interesu za prirodne vrijednosti Međimurske županije i prirodoslovlje između polaznika programa "Mladi čuvari prirode Međimurja“ i nepolaznika;

Polaznici programa "Mladi čuvari prirode Međimurja“ imaju pozitivnije stavove i veće znanje o prirodnim vrijednostima Međimurske županije od nepolaznika.

\section{METODE}

U radu su korištene dvije istraživačke metode: analiza relevantne teorijske i empirijske literature te anketna metoda. Anketna metoda je poseban oblik ne-eksperimentalnog istraživanja koje kao osnovni izvor podataka koristi osobni iskaz o mišljenjima, uvjerenjima, stavovima i ponašanju, pribavljen odgovarajućim standardiziranim nizom pitanja (Milas, 2009). Ciljana populacija su polaznici programa „Mladi čuvari prirode Međimurja“ 2009. godine, a kao kontrolna skupina njihovi vršnjaci koji nisu 
sudjelovali u programu. Online anketa je provedena sredinom kolovoza 2015. godine te je istraživanjem obuhvaćeno sveukupno 32 ispitanika (16 sudionika programa „Mladi čuvari prirode Međimurja" te 16 nesudionika).

Anketni upitnik je sadržavao pet uvodnih pitanja (tip mjesta stanovanja, spol, dob, završena srednja škola, studentski status) te deset pitanja od čega devet zatvorenog tipa, a jedno otvorenog. Ispituje se interes ispitanika prema pojedinim područjima znanosti, mišljenje sudionika programa „Mladi čuvari prirode Međimurja“ o utjecaju na interes za zaštitu prirode i prirodoslovlje te na koji način je on ostvaren. Nesudionici programa su odgovarali na pitanje o razlogu nesudjelovanja. Svi ispitanici su ispitani o sastavnicama prirode, kategoriji zaštite rijeke Mure i Drave te značaju Spomenika prirode Bedekovićeve grabe u biološkom smislu. Posljednja tri pitanja ispituju kada se obilježava Dan zaštite prirode, gdje je sjedište „Međimurske prirode“ te trebaju navesti jednu strogo zaštićenu vrstu. Anketni upitnik je popunjavan prosječno 7 minuta.

\section{REZULTATI}

Anketiranjem je obuhvaćeno 32 ispitanika s područja Međimurske županije (statistika uzorka prikazana je u tablici 2), pri čemu je polovica polazila program „Mladi čuvari prirode Međimurja“, a druga polovica nije. Velika većina ispitanika ima prebivalište u seoskom tipu naselja, a manji broj u gradskom. $\mathrm{U}$ ispitivanju je sudjelovalo 10 muških i 22 ženskih ispitanika. Većina ispitanika (87,5\%) je u dobi od 18 i 19 godina i završili su srednju školu. Najviše ispitanika je završilo Gimnaziju Josipa Slavenskog Čakovec i Srednju školu Čakovec, a ostatak ispitanika Ekonomsku i trgovačku školu Čakovec ili neku drugu na području Međimurja. Gotovo svi ispitanici su upisali fakultet $(84,4 \%)$ ili planiraju.

Tablica 2. Statistika uzorka

\begin{tabular}{|l|c|}
\hline Obilježje & Vrijednost /broj ispitanika \\
\hline Broj ispitanika & 32 \\
\hline Polaznici programa „Mladi čuvari prirode Međimurja“ & 16 \\
\hline Nepolaznici programa „Mladi čuvari prirode Međimurja“ & 16 \\
\hline Tip mjesta stanovanja ispitanika & 7 \\
\hline Gradsko & 25 \\
\hline Seosko & 10 \\
\hline Spol ispitanika & 22 \\
\hline Muški & \multicolumn{1}{|c|}{} \\
\hline Ženski & 14 \\
\hline Dob ispitanika & 14 \\
\hline 18 godina & 4 \\
\hline 19 godina & 9 \\
\hline 20 godina & 13 \\
\hline Završena srednja škola & 4 \\
\hline Srednja škola Čakovec & 6 \\
\hline Gimnazija Josipa Slavenskog Čakovec & 27 \\
\hline Ekonomska i trgovačka škola Čakovec & 4 \\
\hline Ostalo & 1 \\
\hline Studentski status & \\
\hline Upisan fakultet/veleučilište & \\
\hline Planira upisati u sljedećem roku & \\
\hline Nije upisao/la i ne planira & \multicolumn{1}{|l}{} \\
\hline \multicolumn{2}{|l|}{} \\
\hline
\end{tabular}

Prvo pitanje ispituje interes ispitanika prema pojedinim područjima znanosti. Kao što je vidljivo na slici 2 najvećem broju sudionika programa je u srednjoj školi prirodoslovno područje bilo najzanimljivije, a 
nesudionicima programa podjednako je zanimljivo prirodoslovno i humanističko područje. Ostala područja znanosti zastupljena su u odgovorima manjeg broja ispitanika.

Distribuciju odgovora sudionika programa na pitanje "Smatrate li da Vam je program „Mladi čuvari prirode Međimurja" potaknuo interes za zaštitu prirode i prirodoslovlje?" prikazuje slika 3 iz koje je vidljivo da je čak $94 \%$ sudionika bilo potaknuto programom, a samo jedan ispitanik nije bio potaknut $\mathrm{i}$ ne navodi razlog.

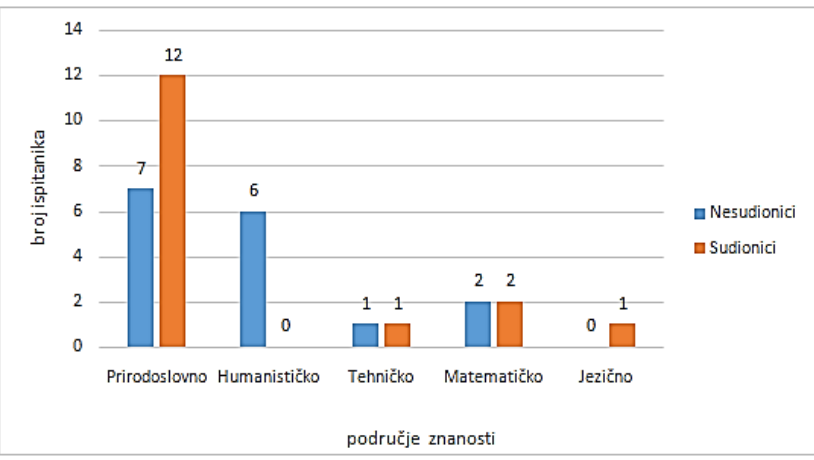

Slika 2. Distribucija odgovora svih ispitanika na pitanje "Iz kojeg područja znanosti su Vam bili najzanimljiviji predmeti u srednjoj školi?"

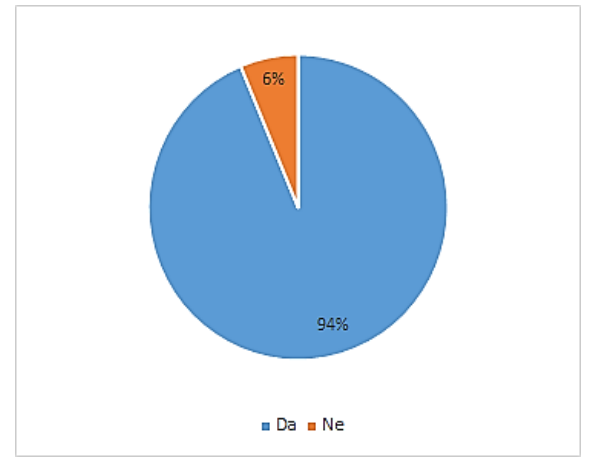

Slika 3. Distribucija odgovora sudionika programa na pitanje “Smatrate li da Vam je program „Mladi čuvari prirode Međimurja" potaknuo interes za zaštitu prirode i prirodoslovlje?"

Trećina sudionika (36\%) je nakon programa češće boravila u prirodi. Također, gotovo trećina sudionika programa (29 \%) se nakon programa aktivno uključila u izvannastavne aktivnosti i dodatni rad u području prirodoslovlja. Nakon programa, neko drugo zaštićeno područje izvan Međimurske županije posjetilo je $21 \%$ ispitanika polaznika programa.

Nesudionici programa (19\%) navode u pitanju "Zašto nisu sudjelovali na programu" (slika 5) da nisu zainteresirani za takve aktivnosti , a čak $81 \%$ njih tvrdi da nisu bili informirani od strane učitelja da se program provodi.

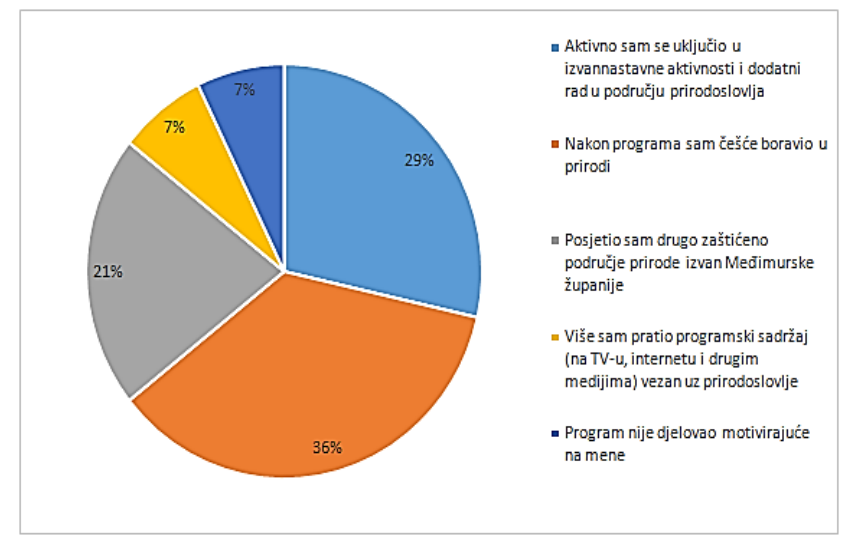

Slika 4. Distribucija odgovora sudionika programa na pitanje "Na koji način Vam je program „Mladi čuvari prirode Međimurja" potaknuo interes za zaštitu prirode i prirodoslovlje?"

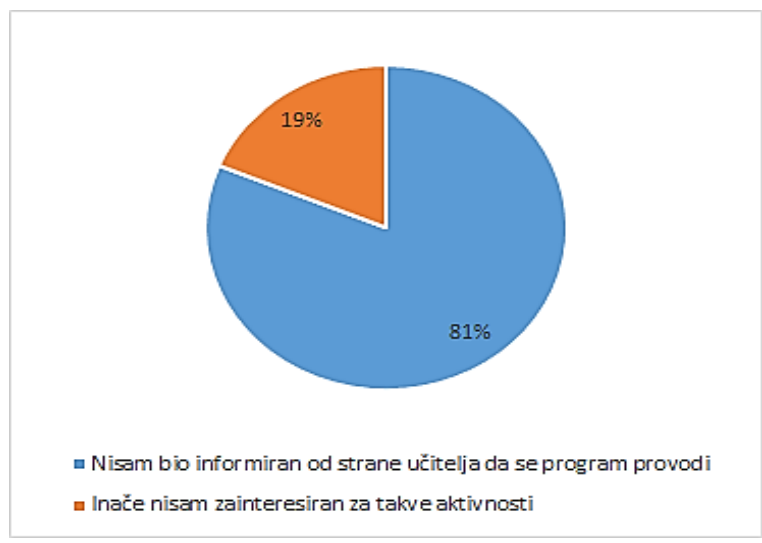

Slika 5. Distribucija odgovora nesudionika programa na pitanje “Zašto niste sudjelovali na programu „Mladi čuvari prirode Međimurja“ ?”

Visokih 94 \% nesudionika (slika 6) i 87 \% sudionika programa (slika 7) odgovara na pitanje "Od kojih se elemenata sastoji priroda” da je to „bioraznolikost, krajobrazna raznolikost i georaznolikost“. 
Gotovo $2 / 3$ ispitanika nesudionika (slika 8) i $94 \%$ sudionika programa (slika 9) navodi da su „rijeka Mura i Drava u Međimurskoj županiji zaštićene u kategoriji regionalnog parka". Ostali nesudionici programa odgovaraju da je to „park prirode ili park šuma“.

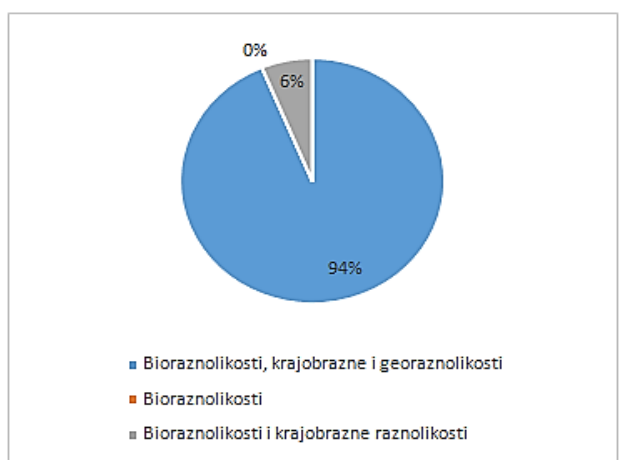

Slika 6. Distribucija odgovora nesudionika programa na pitanje "Prema Vašem mišljenju, od kojih se elemenata sastoji priroda?"

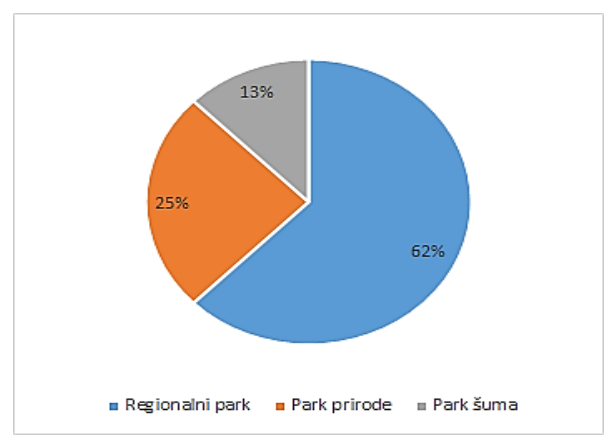

Slika 8. Distribucija odgovora nesudionika programa na pitanje "Rijeka Mura i Drava u Međimurskoj županiji su zaštićene u kojoj kategoriji?"

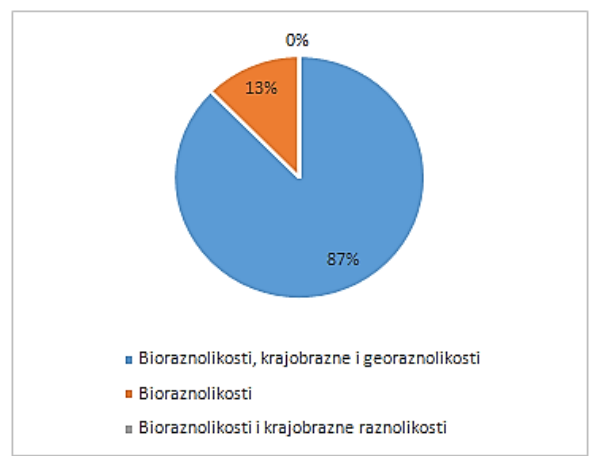

Slika 7. Distribucija odgovora sudionika programa na pitanje "Prema Vašem mišljenju, od kojih se elemenata sastoji priroda?"

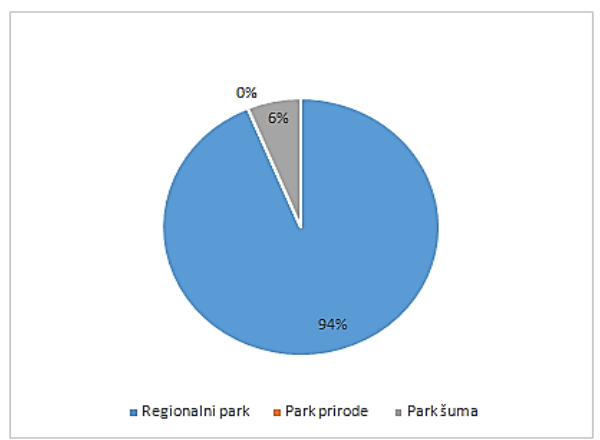

Slika 9. Distribucija odgovora sudionika programa na pitanje "Rijeka Mura i Drava u Međimurskoj županiji su zaštićene u kojoj kategoriji?"

Svih 100 \% ispitanika sudionika programa (slika 11) odgovara da je "Spomenik prirode Bedekovićeve grabe značajan u biološkom smislu po simbiozi plavaca i krvare", dok taj isti odgovor navodi visokih 82 $\%$ nesudionika (slika 10). Ostali nesudionici navode da su „Bedekovićeve grabe poznate po dabrovim nastambama, jedinstvenim šumama ili močvarnim staništima“.

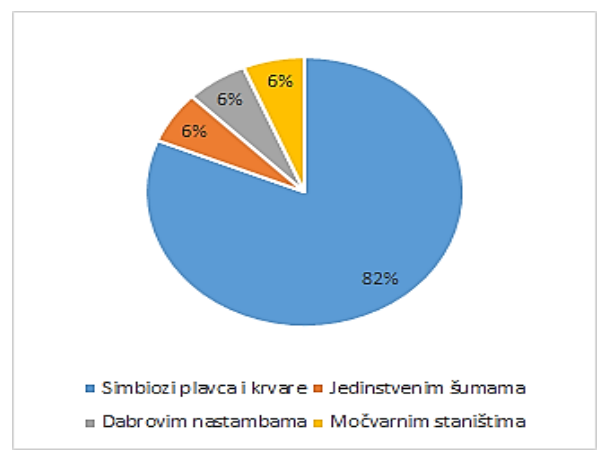

Slika 10. Distribucija odgovora nesudionika programa na pitanje "Spomenik prirode Bedekovićeve grabe značajan je u biološkom smislu po:"

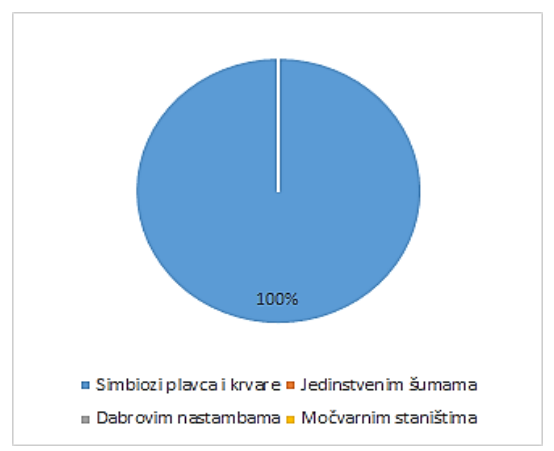

Slika 11. Distribucija odgovora sudionika programa na pitanje "Spomenik prirode Bedekovićeve grabe značajan je u biološkom smislu po:" 
Datum Dana zaštite prirode u Republici Hrvatskoj kao 22. svibnja navodi $63 \%$ nesudionika programa, dok $31 \%$ odgovara da je to 22. travnja (slika 12). Sudionici programa, njih $87 \%$, navodi datum Dana zaštite prirode kao 22. svibnja, a svega $13 \%$ odgovara da je to 22. travnja (slika 13). Preko polovice nesudionika programa (56 \%) smatra da je sjedište „Međimurske prirode“ u Svetom Martinu na Muri (slika 14), 19 \% smatra da je u Čakovcu, a samo 25 \% navodi da je sjedište u Križovcu. Svi sudionici programa odgovaraju da je sjedište „Međimurske prirode“ u Križovcu (slika 15).

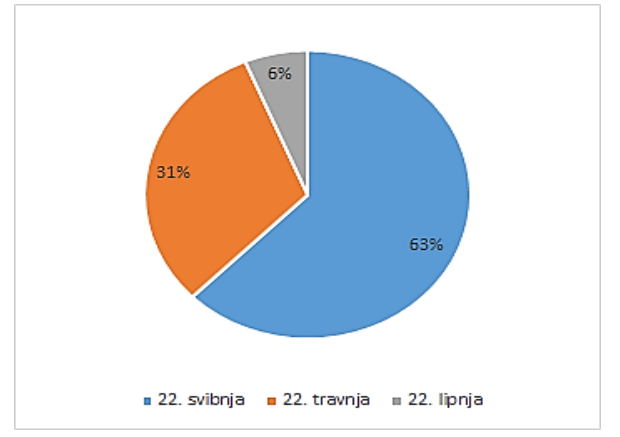

Slika 12. Distribucija odgovora nesudionika programa na pitanje "Kojeg datuma obilježavamo Dan zaštite prirode u Republici Hrvatskoj?”

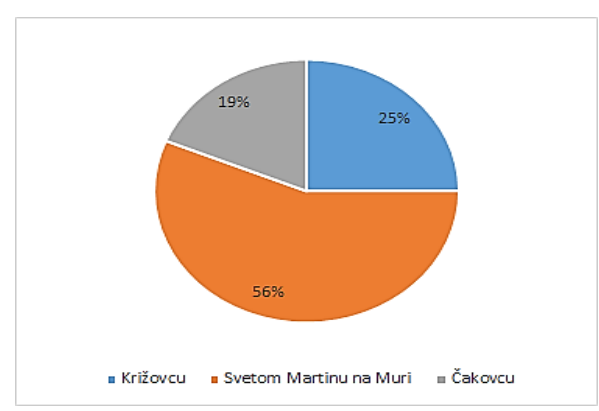

Slika 14. Distribucija odgovora nesudionika programa na pitanje "U kojem naselju Međimurske županije se nalazi sjedište Međimurske prirode - Javne ustanove za zaštitu prirode?"

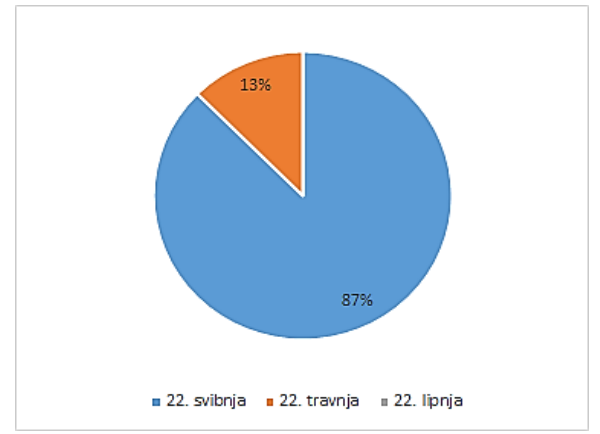

Slika 13. Distribucija odgovora sudionika programa na pitanje "Kojeg datuma obilježavamo Dan zaštite prirode u Republici Hrvatskoj?"

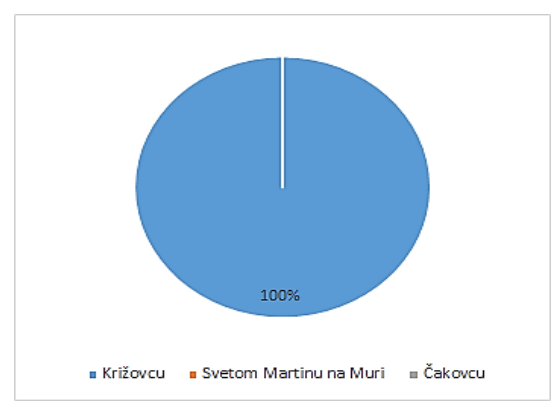

Slika 15. Distribucija odgovora sudionika programa na pitanje "U kojem naselju Međimurske županije se nalazi sjedište Međimurske prirode - Javne ustanove za zaštitu prirode?"

Na pitanje da navedu jednu strogo zaštićenu vrstu koja obitava u Međimurskoj županiji ispitanici sveukupno navode devet različitih vrsta. Nesudionici programa (slika 16) navode "leptir plavac $i$ visibaba" kao najčešće odgovore, a sudionici programa (slika 17) "leptir plavac i kockavica". Nesudionici programa još navode kao odgovor ",kockavicu, ćuk, pticu sjenicu, obalnu lastavicu, rodu i krticu“, a sudionici programa "visibabu, rodu i vidru“.

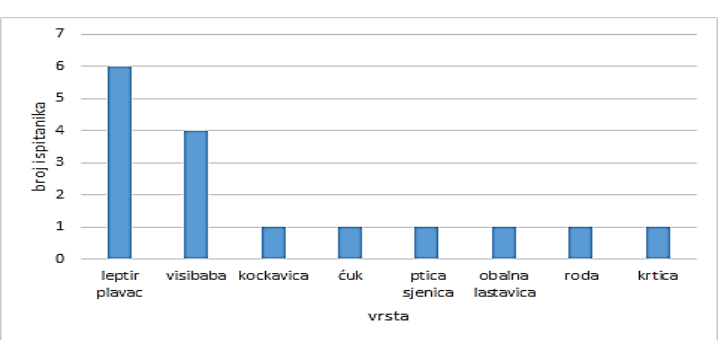

Slika 16. Distribucija odgovora nesudionika programa na pitanje "Navedite jednu strogo zaštićenu vrstu koja obitava u Međimurskoj županiji"

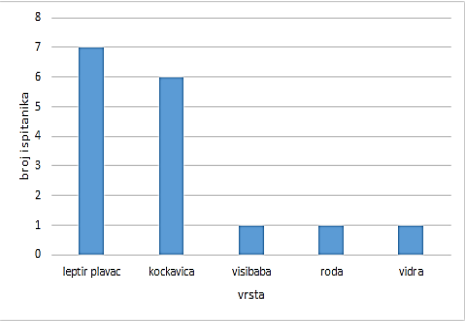

Slika 17. Distribucija odgovora sudionika programa na pitanje "Navedite jednu strogo zaštićenu vrstu koja obitava u Međimurskoj županiji" 


\section{RASPRAVA}

Programi u području prirodoslovlja mogu biti uspješni ukoliko su dobro definirani ciljevi, učenje uzbudljivo, vođeno i traži od polaznika razmišljanje. U svakom slučaju uvijek treba uzeti u obzir i individualne osobine te potrebe onih koji uče (Andrilović i Čudina, 1985). Rasprava o rezultatima istraživanja pratit će slijed kako su rezultati i predstavljeni u prethodnom poglavlju. Hipoteza koju ovaj rad apostrofira, pretpostavlja da su polaznici afirmativnog stava prema prirodi, prirodnoj baštini i prirodoslovlju kao nastavnim sadržajima. Navedeno potvrđuje i činjenica da je 75 \% ispitanika koji su polazili program „Mladi čuvari prirode Međimurja“ navelo da su im predmeti iz prirodoslovnog područja znanosti bili najzanimljiviji u srednjoj školi. S druge strane, nepolaznici programa u jednakom udjelu iskazuju interes prema predmetima prirodoslovnog i humanističkog područja znanosti.

Ukoliko analiziramo rezultate odgovora sudionika na drugo pitanje, vidljivo je da je program "Mladi čuvari prirode Međimurja“ potaknuo interes sudionika za zaštitu prirode i prirodoslovlje. Naime, $36 \%$ polaznika je nakon programa češće boravilo u prirodi, $29 \%$ polaznika se aktivno uključilo u izvannastavne aktivnosti ili dodatni rad u svojim matičnim obrazovnim ustanovama što je sasvim sigurno pozitivno utjecalo i na daljnji angažman u redovnoj nastavi prirodoslovlja. Terenski rad u programu potaknuo je više od jedne petine polaznika da posjete neko od zaštićenih područja izvan Međimurske županije, no taj podatak treba objektivno sagledati i kroz prizmu mogućnosti da su ta područja posjećena kroz putovanja u organizaciji škola. U četvrtom pitanju svega $19 \%$ ispitanika (onih koji nisu sudjelovali u programu) nije pokazalo interes za sudjelovanjem, a čak $81 \%$ tvrdi da nisu bili informirani od strane predmetnih učitelja. Taj podatak nije u potpunosti u skladu s odazivom osnovnih škola u navedeni program. Naime, 18 osnovnih škola, što je $60 \%$ svih osnovnih škola Međimurske županije, uključilo se aktivno u program. Moguće je da je dio učitelja odabrao polaznike prema njihovim sklonostima, no takve aktivnosti vrlo rijetko prođu nezapaženo u razrednoj zajednici stoga se tvrdnja da nisu bili informirani od strane učitelja u toj mjeri ne može u potpunosti prihvatiti.

Svi ispitanici su u jako visokom udjelu ispravno odgovorili što je priroda, da je to sveukupna bioraznolikost, krajobrazna raznolikost i georaznolikost. Navedeno se može pojasniti činjenicom da se o sastavnicama prirode govori u 5. razredu osnovne škole u sklopu nastavnih sadržaja prirode.

S obzirom na činjenicu da su polaznici programa učili o svih 9 kategorija zaštićenih područja u Republici Hrvatskoj, pitanjem o kategoriji zaštite rijeke Mure i Drave ispituje se razlika u poznavanju kategorija zaštićenih područja. Gotovo svi polaznici programa ( 94 \%) znaju da su rijeke Mura i Drava zaštićene u kategoriji regionalni park, za razliku od nepolaznika (62 \%), jer je u sklopu programa (2009. godine) istaknuto da je područje koje smo posjetili tijekom terenskog obilaska u postupku proglašenja regionalnim parkom. U vrijeme provođenja programa područje rijeke Mure i Drave u Hrvatskoj je bilo pod preventivnom zaštitom, a u veljači 2011. godine je na snagu stupila trajna zaštita u kategoriji regionalni park. Četvrtina nepolaznika programa navodi da su rijeke Mura i Drava zaštićene kao park prirode, što potvrđuje činjenicu nepoznavanja razlike između kategorija zaštićenih područja.

Kako je ovaj edukativni program temeljen na pretpostavci da odabrane teme iz prirodoslovlja treba primijeniti u svrhu edukacije učenika šestih i sedmih razreda osnovne škole, posebice potaknuvši učenike u svladavanju osnovnih prirodoslovnih i ekoloških pojmova s naglaskom na učenje o prirodnim vrijednostima Međimurske županije, za očekivati je da će sudionici na pitanja s temama iz zaštite prirode o kojima su bili educirani kroz program s visokim postotkom odgovarati točno u odnosu na 
nesudionike. Svi sudionici programa odgovaraju da je Spomenik prirode Bedekovićeve grabe značajan u biološkom smislu po simbiozi plavaca i krvare i znaju da je sjedište „Međimurske prirode“ u Križovcu što je u skladu s očekivanjima s obzirom da su to zaštićeno područje posjetili tijekom programa i boravili u samom sjedištu ustanove. Visokih 82 \% nesudionika programa odgovaraju da je Spomenik prirode Bedekovićeve grabe značajan u biološkom smislu po simbiozi plavaca i krvare, a to objašnjavamo da je podatak o kojem su vjerojatno učili u školi ili čuli putem različitih medija. Isto se odnosi i na datum Dana zaštite prirode u Republici Hrvatskoj koji kao 22. svibnja navodi $63 \%$ nesudionika programa. Sudionici programa, njih $87 \%$, navodi datum Dana zaštite prirode kao 22. svibnja. Ovaj nešto manje očekivani rezultat je rezultat toga što su svi ponuđeni datumi u odgovorima iz ankete datumi važni u zaštiti prirode pa su ih zbunili. Preko polovice nesudionika programa (56 \%) navodi da je sjedište „Međimurske prirode“ u Svetom Martinu na Muri, a samo 25 \% navodi da je sjedište u Križovcu. Ovaj podatak ne iznenađuje jer je Križovec manje poznato naselje za razliku od Svetog Martina na Muri koji se puno spominje u medijima.

U pitanju otvorenog tipa, gdje se traži navođenje jedne strogo zaštićene vrste, bitno je napomenuti da su svi navedeni nazivi vrsta na hrvatskom jeziku. Ispitanici još nisu dovoljno percipirali važnost latinskog nazivlja u navođenju vrsta odnosno za pretpostaviti je da ne znaju latinske nazive. Gledajući sve ispitanike, najčešće navođena vrsta je leptir plavac. Navedeno se može pojasniti činjenicom da se o ovim leptirima puno govori s aspekta ugroženosti, prvenstveno u medijima na području Međimurske županije. Druga vrsta po zastupljenosti je kockavica, a nepolaznici programa u visokom udjelu navode i visibabu. Navedeno se može dovesti u vezu s čestim spominjanjem visibabe u kontekstu dozvole ili zabrane branja proljetnica. Također, ispitanici nisu naveli točne nazive vrsta već su generalizirali. Primjerice, da li su kod navođenja roda mislili na bijelu ili crnu rodu te kod leptira plavca koja točno vrsta plavca - veliki livadni plavac, zagasiti livadni plavac, veliki plavac, močvarni plavac i sl. Iz navedenih odgovora zaključujemo da ispitanici ne obraćaju pažnju na točne nazive vrsta te da im nije jasan zakonski okvir zaštite vrsta odnosno što znači da je neka vrsta strogo zaštićena. Tematika je jako kompleksna, djelomično i zbog čestog mijenjanja zakonskih propisa te za sada nije dovoljno pojašnjen u nastavnim sadržajima. U Zakonu o zaštiti prirode iz 2005. godine postojale su tri kategorije zaštićenih vrsti - strogo zaštićena divlja vrsta, zaštićena divlja vrsta te zaštićena zavičajna udomaćena vrsta. Važeći Zakon o zaštiti prirode iz 2013. godine štiti samo strogo zaštićene vrste te je time tematika pojednostavljena. Također, postoje i međunarodni okviri zaštite vrsta kroz ekološku mrežu Natura 2000 te pripadajuće direktive kao i Crvene knjige koje se odnose na kategorije ugroženosti vrsta prema Međunarodnoj uniji za očuvanje prirode (engl.: International Union for Conservation of Nature ili IUCN).

\section{ZAKLUČAK}

Program "Mladi čuvari prirode Međimurja" novi je pristup učenju o prirodnim vrijednostima Međimurske županije. U radu su potvrđene hipoteze:

Postoji razlika u interesu za prirodne vrijednosti Međimurske županije i prirodoslovlje između polaznika programa „Mladi čuvari prirode Međimurja“ i nepolaznika. Polaznici programa imaju veći interes za istraživane teme od nepolaznika.

Polaznici programa "Mladi čuvari prirode Međimurja“ imaju pozitivnije stavove i veće znanje o prirodnim vrijednostima Međimurske županije od nepolaznika. 
Dobiveni rezultati potiču na daljnja istraživanja te provedbu sličnih programa kojima bi se još detaljnije ukazalo na važnost izvanškolskih edukativnih programa u obrazovanju, posebice primarnom obrazovanju. Edukativni programi, a obzirom na kretanja obrazovne misli prema usvajanju kompetencija odnosno ishodima učenja, mogu samo pridonijeti razvijanju spoznaja o utjecaju takvih sadržaja na obrazovna postignuća učenika u nastavi prirodoslovnih predmeta te dati mogućnost uspostavljanja modela za širu primjenu u obrazovnom sustavu.

\section{LITERATURA}

Andrilović, V., Čudina M. 1985. Psihologija učenja i nastave, Školska knjiga, Zagreb.

Baranović, B. 2006. Nastavni programi iz perspektive nastavnika i učitelja; u: Nacionalni kurikulum za obvezno obrazovanje u Hrvatskoj: različite perspektive, Baranović B. (ur.), Institut za društvena istraživanja, 107-179, Zagreb.

Bunić I. 2006. Priručnik za interpretaciju zaštićenih područja, Državni zavod za zaštitu prirode, Zagreb.

Council of the European Union 2001. Report from Education Council to the European Council on the Concrete Future Objectives of Education and Training Systems, Brussels.

De Zan I. 1999. Obrazovanje i odgoj za okoliš, u: Napredak - časopis za pedagogijsku teoriju i praksu, 144, 3, 328-339, Zagreb. European Commission 2007. EUR22845 - Science Education NOW, A renewed Pedagogy for the Future of Europe, Office for Official Publications of the European Communities, Luxemburg.

Gray, M. 2005. Geodiversity and Geoconservation: What, Why and How?, The George Wright Forum 22, 3, 4-12.

George, D. 2005. Obrazovanje darovitih - kako identificirati i obrazovati darovite i talentirane učenike, Educa, Zagreb. Jelavić, F. 1995. Didaktičke osnove nastave, Naklada Slap. Jastrebarsko.

Klausmeier, H.J., Sipple, T.S. 1980. Learning and Teaching Concepts - A strategy for Testing Appclications of Theory, Academie Press, New York.

Lenardić, M., Radošević, S., Jurlin, K. 2005. Godišnje izvješće o konkurentnosti Hrvatske (za 2004. godinu), Nacionalno vijeće za konkurentnost, Zagreb.

Martinić, I. 2010. Upravljanje zaštićenim područjima prirode - planiranje, razvoj i održivost, Sveučilište u Zagrebu, Šumarski fakultet, Zagreb.

Matas, M. 1999. Geografski pristup ekološkom odgoju i obrazovanju odgajatelja i odgajanika, u: Ekologija - korak bliže djetetu, Uzelac, V. (ur.), Adamić, 78-86, Rijeka.

Matijević, M. 2004. Ocjenjivanje u osnovnoj školi, Tipex, Zagreb.

Milas, G. 2009. Istraživačke metode u psihologiji i drugim društvenim znanostima, Naklada Slap, Jastrebarsko.

Tilden, F. 1977. Interpreting Our Heritage, University of North Carolina Press.

Štrbić, M. 2006. Prikaz skupa Europska iskustva i nacionalni kurikulum, u: Metodika, 7, 2, 367 -379, Učiteljski fakultet, Zagreb. 


\title{
Analysis of opinions and interests of high school students about natural values Međimurje county
}

\author{
${ }^{1}$ Monika Cindrić1, Mihaela Mesarić2, Dražen Crnčec $^{3}$ \\ ${ }^{1}$ High school Čakovec \\ monica.pbk@gmail.com \\ ${ }^{2}$ Nature of Međimurje - Public institution for nature protection \\ ${ }^{3}$ Primary school Sveti Martin na Muri
}

\begin{abstract}
The objective of ecological education is to transfer the message about the importance and necessity of preserving natural and cultural values. The interpretation is considered as the most powerful tool for ecological education. The founding father of interpretation, Freeman Tilden said: "Through interpretation, understanding; through understanding, appreciation; through appreciation, protection." Employees of Nature of Međimurje public institution associated by two teachers performed an educational program named "Junior Rangers of Međimurje" in the year 2009, using both direct and indirect forms of interpretation. Forty pupils from the sixth and seventh grade of primary schools of the Međimurje County attended this educational program. The program was performed as series of lectures, workshops and field work. The process took place during the spring of 2009 with goals of ecological education and to increase the interest for natural sciences among primary school pupils. In this paper, authors present the influence of the "Junior Rangers of Međimurje" program on the development of positive attitude toward protected natural values in the Međimurje County as well as extension of the pupil's interest for natural sciences. The method of online survey was used to determine the results. Two groups were included in survey: participants of the "Junior Rangers of Međimurje" 2009 program and non-participants as the control group. Including pupil's standpoints, the survey tested interests for natural sciences with special emphasis on protected natural values. The analysis confirmed the hypothesis that there is a significant difference between standpoints of the experimental and the control group. Participants of the program express greater knowledge about natural values of Međimurje County.
\end{abstract}

Keywords: nature; protected natural values; junior rangers; attitudes about nature 